\title{
Pola Pengasuhan Positif Orangtua pada Anak Usia Dini Selama Belajar Dari Rumah Dimasa Pandemi Covid-19
}

\author{
Rieyani Okta Sumbawa ${ }^{1,}$ Mila Karmila ${ }^{2}$ \\ Universitas PGRI Semarang ${ }^{12}$, Indonesia \\ rieyani.okta.sumbawa14@gmail.com ${ }^{1}$, milakarmila@upgris.ac.id ${ }^{2}$
}

\begin{tabular}{l}
\hline Abstract \\
\hline The Covid 19 pandemic in Indonesia has changed the \\
order of life in all aspects and does not take into \\
Positive Parenting; \\
account the education aspect, because until now cases \\
Early Childhood. \\
of citizens exposed to the Covid-19 virus in Indonesia \\
continue to increase. The teaching and learning \\
process which is usually carried out in schools and \\
accompanied by teachers is now shifting learning to be \\
done at home and accompanied by parents. To realize \\
advanced Indonesian education, since the Covid-19 \\
virus entered the territory of Indonesia, the \\
government in Indonesia immediately followed up on \\
the case in a way that could be done, namely by \\
changing the education system in Indonesia into \\
distance learning or called BDR, this condition made \\
parents take over duties and functions of teachers in \\
schools. This study aims to involve parents more in \\
mentoring children's learning, share information with \\
teachers and parents on how positive parenting can be \\
done in the midst of the Covid-19 pandemic. The \\
research methodology used is a literature study which \\
is the material for reviewing seven to ten studies \\
conducted. relevant to the positive parenting pattern \\
of parents while studying from home during the \\
coviD-19 pandemic. Parents are expected to provide \\
positive and better caregivers to assist children in \\
learning at home during the Covid-19 pandemic, so \\
the result is positive parenting by assisting children in \\
doing school assignments, supporting and facilitating \\
children in learning, establishing good communication \\
between families, choosing patterns proper parenting, \\
respecting children's opinions, making rules at home \\
and giving a reward. The role of parents in assisting \\
children's learning at home is very much needed, to \\
support the success of children's education. Thus, \\
children will not feel alone and are more enthusiastic in \\
participating in learning from home during the Covid-
\end{tabular}


19 pandemic.

\begin{tabular}{|c|c|}
\hline \multicolumn{2}{|l|}{ Abstrak } \\
\hline $\begin{array}{l}\text { Pandemi Covid } 19 \text { di Indonesia merubah tatanan } \\
\text { kehidupan disemua aspek dan tak terkecuali aspek } \\
\text { pendidikan, karena hingga saat ini kasus warga } \\
\text { terpapar virus covid-19 di Indonesia terus } \\
\text { meningkat.Proses belajar mengajar yang biasanya } \\
\text { dilaksanakan disekolah dan didampingi oleh guru kini } \\
\text { pembelajaran beralih dilakukan dirumah dan } \\
\text { didampingi oleh orang tua. Untuk mewujudkan } \\
\text { pendidikan Indonesia yang maju, sejak saat virus } \\
\text { Covid-19 masuk wilayah Indonesiapemerintah di } \\
\text { Indonesia langsung menindak lanjuti kasus tersebut } \\
\text { dengan cara yang dapat dilakukan yaitu dengan } \\
\text { mengubah sistem pendidikan di Indonesia menjadi } \\
\text { pembelajaran jarak jauh atau biasa disebut BDR, } \\
\text { kondisi ini membuat orangtua mengambil alih tugas } \\
\text { dan fungsi guru disekolah. penelitian ini bertujuan } \\
\text { untuk mengajak keterlibatan orangtua secara lebih } \\
\text { dalam pendampingan belajar anak, Membagikan } \\
\text { informasi pada guru dan orangtua bagaimana } \\
\text { pengasuhan positif yang dapat dilakukan ditengah } \\
\text { pandemic Covid-19. Metodologi penelitian yang } \\
\text { digunakan adalah studi pustaka yang merupakan } \\
\text { bahan untuk mengkaji tujuh sampai sepuluh penelitian } \\
\text { relevan mengenai pola pengasuhan positif orangtua } \\
\text { selama belajar dari rumah dimasa pandemi covid-19. } \\
\text { Orangtua diharapkan memberikan pengasuhan yang } \\
\text { positif dan lebih baik untuk membantu dalam } \\
\text { kelancaran belajar anak dirumah dimasa pandemi } \\
\text { Covid-19, Adapun hasilnya adalah pengasuhan positif } \\
\text { dengan mendampingi anak dalam mengerjakan tugas } \\
\text { sekolah, mendukung dan memfasilitasi anak dalam } \\
\text { belajar, menjalin komunikasi yang baik antar keluarga, } \\
\text { memilih pola asuh yang tepat, menghargai pendapat } \\
\text { anak,membuat peraturan dirumah dan memberikan } \\
\text { sebuah hadiah (Reward). Peran orangtua dalam } \\
\text { pendampingan belajar anak dirumah sangat } \\
\text { dibutuhkan, untuk menunjang keberhasilan pendidikan } \\
\text { anak.Dengan demikian anak tidak akan merasa sendiri } \\
\text { dan lebih semangat dalam mengikuti pembelajaran } \\
\text { dirumah dimasa pandemic Covid-19 }\end{array}$ & $\begin{array}{c}\text { Kata Kunci: } \\
\text { Pengasuhan Positif; } \\
\text { Pandemi Covid-19; } \\
\text { Anak Usia Dini. }\end{array}$ \\
\hline $\begin{array}{l}\text { Diterima :16 Juli } 2021 \text { Direvisi: } 17 \text { Agustus 2021;Diterbitk } \\
\end{array}$ & :28 Agustus 2021 \\
\hline $\begin{array}{l}\text { http://doi.org/10.19105/kiddo.v2i2.4790 } \\
\text { (c) () () () }\end{array}$ & $\begin{array}{l}\text { San Islam Anak Usia Dini } \\
\text { egeri Madura, Indonesia }\end{array}$ \\
\hline
\end{tabular}

\section{Pendahuluan}

Saat ini pandemi Covid-19 di seluruh wilayah Indonesia mengalami pertumbuhan yang sangat pesat. Virus Covid-19 pertama kali muncul di Wuhan, Provinsi Hubei, Tiongkok. Virus ini diduga muncul karena adanya 
sebuah pasar makanan di Wuhan yang menjual bebagai jenis hewan hidup maupun hewan yang sudah mati. Menurut (Nuraini, 2020) dalam (Windhiyana, E., 2020) Virus ini telah tersebar di seluruh dunia, termasuk Indonesia sejak awal bulan Maret 2020, Berdasarkan data dari covid19.go.id di Negara Indonesia sampai dengan 27 Februari 2021 tercatat sebanyak 1.329.074 kasus, 1.136 .054 Sembuh, dan 35.981 meninggal dunia dan sisanya masih dalam perawatan. Hingga saat ini kasus positif Covid-19 di Indonesia masih terus meningkat.

Pemerintah Indonesia langsung menindak lanjuti kasus tersebut dengan berbagai upaya untuk memutus rantai penyebaran Covid-19 diawali dari PSBB (Pembatasan Sosial Berskala Besar), dengan keluarnya PP Nomor 21 Tahun 2020 dalam rangka percepatan penanganan Covid-19. Salah satu tindakan pemerintah adalah melakukan Social Distancing selama 14 hari untuk meminimalisir penyebaran virus tersebut. Menurut Center for Disease (CDC) dalam (Kosasih, 2020) bahwa Social Distancing adalah upaya menjauhi sebuah perkumpulan, menghindari pertemuan massal melibatkan banyak orang, dan menjaga jarak antar manusia. Pembatasan sosial/ menjaga jarak yang dilakukan untuk mencegah penularan COVID-19 agar tidak menyebar luas di Negara Indonesia.

Pandemi Covid-19 Di Indonesia berdampak pada seluruh aspek kehidupan mulai dari perekonomian menjadi merosot, harga bahan pokok naik, harga alat Kesehatan meningkat drastis, dan terutama pada alat kesehatan seperti alat pelindung diri, hingga sistem Pendidikan di Indonesia yang berubah. Dalam aspek pendidikan pandemi Covid-19 menuntut semua elemen pendidikan untuk beradaptasi dan melanjutkan seluruh kegiatan pembelajaran, Sejak Covid-19 ditetapkan sebagai pandemi di Indonesia pada tanggal 11 Maret 202, Pendidikan di Indonesia tidak dapat dikatakan terhenti tetapi sistem yang berlaku menjadi pembelajaran jarak jauh atau biasa disebut BDR (Belajar Dari Rumah) sesuai dengan surat edaran Mendikbud No. 4 tahun 2020 tentang Pelaksanaan Kebijakan Pendidikan Dalam Masa Darurat Penyebaran Coronavirus Disease (Covid19). Dengan adanya kebijakan pemerintah untuk belajar dari rumah, maka peran yang biasanya dilaksanakan oleh satuan pendidikan, sekarang telah berganti fungsi disatuan keluarga yang menuntut orangtua terlibat aktif dalam mendampingi anak dengan pola asuh yang sesuai dalam kegiatan belajar dari rumah.

Situasi yang terjadi saat ini, menuntut keterlibatan orang tua secara lebih maksimal dan melakukan komunikasi intens dengan guru dalam melaporkan perkembangan anaknya. Dapat dikatakan bahwa situasi saat ini mengembalikan hakikat Pendidikan anak dalam keluarga. Sikap orang tua meliputi cara orangtua memberikan aturan-aturan/hadiah/ hukuman, cara orangtua menunjukan otoritasnya, dan cara orangtua memberikan perhatian serta tanggapan terhadap anaknya Agustin (2015). Friedman (dalam Slameto, 2010) menyatakan bahwa peran orangtua dalam kegiatan pembelajaran sangat dipengaruhi oleh beberapa faktor, antara lain: (a) status sosial yang ditentukan oleh tingkat pendidikan, pekerjaan, dan penghasilan; (b) bentuk keluarga; (c) tahap perkembangan keluarga dimulai dari terjadinya pernikahan hingga tahap persiapan menjadi orangtua; dan (d) faktor model peran. Peran orangtua terhadap anak meliputi pendampingan pada anak, menjalin komunikasi yang baik, 
memberikan kesempatan atau kepercayaan, memberikan pengawasan agar anak tetap dalam pengawasan dan arahan yang baik, memberikan motivasi, mengarahkan anak serta memberikan pengasuhan dan pembelajaran yang efektif Ingram et al (2015).

Kegiatan pembelajaran dari rumah berdampak pada pola pengasuhan orangtua dirumah. Pengasuhan dirumah sebelum dan sesudah pandemi tentu saja secara signifikan mengalami perubahan, untuk itu pola pengasuhan dimasa pandemi menjadi hal yang yang wajib dan sangat penting bagi oragtua hal itu sesuai dengan pendapat Mutiah, yang menyatakan bahwa mengasuh, membina, dan mendidik anak dirumah merupakan kewajiban bagi setiap orangtua dalam membentuk kepribadian anak Mutiah (2012). Orangtua dirumah membantu dalam mempersiapkan kegiatan pembelajaran hingga dalam pendampingan, pola asuh yang diterapkan oleh orangtua sesuai dengan komunikasi yang tepat dapat membentuk perilaku positif anak Ramadhani (2013). Maka orangtua diharapkan memiliki keterampilan komunikasi yang efektif, sehingga dapat menunjang upaya pengasuhan dan pendidikan bagi anak-anak di dalam lingkungan keluarga.

Komunikasi merupakan salah satu kunci suskses dalam kehidupan sebuah keluarga, Lasswell Effendy, O (1984:10) mengemukakan bahwa komunikasi adalah proses penyampaian suatu pesan oleh komunikator kepada komunikan melalui media yang dapat menimbulkan efek tertentu. Hurlock (1999) menyatakan bahwa ada beberapa factor yang dapat mempengaruhi pola asuh orang tua yaitu karakteristik orangtua yang berupa kepribadian, setiap orang tua berbeda dalam tingkat energi, kesabaran, intelegensi, sikap, dan kematangannya. Karakteristik tersebut akan mempengaruhi kemampuan orangtua untuk mememuhi tuntutan peran sebagai orangtua dan bagaimana tingkat sensitifan orang tua terhadap kebutuhan anak-anaknya. Melansir laman Ruang Guru PAUD Kementrian Pendidikan dan Kebudayaan (Kemendikbud), Jumat $(17 / 7 / 2020)$ terdapat pengalaman orang tua yang dibagikan dalamsesi Webinar Orang Tua berbagi "Rumahku Sekolahku". Salah satu orang tua siswa PAUD Terpadu Anak Saleh, Malang, Jawa Timur, Wempi Maron menjelaskan beberapa masalah dalam pelaksanaan pembelajaran yang dilakukan dari rumah tersebut, antara lain ketidaksiapan menerima perubahan, perilaku anak yang berbeda (moody), komunikasi dengan guru yang terhambat, dan rendahnya tingkat ketersediaan perangkat teknologi informasi (edukasi.kompas.com).

Adanya pembelajaran jarak jauh saat ini mengakibatkan orang tua mengalami kendala dalam pendampingan belajar seperti kurangnya pemahaman materi oleh orang tua, kesulitan orang tua dalam menumbuhkan minat belajar anak, tidak memiliki cukup waktu untuk mendampingi anak karena harus bekerja, kesulitan orang tua dalam mengoperasikan gadget, dan kendala terkait jangkauan layanan internet hingga membuatnya merasa tidak sabar dan marah dalam mendampingi anak belajar dari rumah. Oleh karena itu, dalam pelaksanaan pembelajaran jarak jauh ini ternyata orang tua memiliki banyak kendala dalam mendampingi anak belajar dirumah. karna itu bagaimana mengelola pengasuhan anak dimasa pandemi. 
Pengasuhan orang tua pada anak usia dini dapat mendukung kompetensi akademik di sekolah, juga dapat mencegah dan mengurangi perilaku yang bermasalah pada anak usia dini. Sayangnya, masih banyak orang tua saat ini menerapkan pengasuhan yang negatif,karena kurangnya pengetahuan dan pemahaman yang salah dalam pengasuhan. Pengasuhan merupakan proses interaksi antara orang tua dan anak dalam mendukung perkembangan fisik, emosi, sosial, intelektual, dan spiritual (Wong, 2001), sehingga anak tumbuh dan berkembang menjadi pribadi yang cerdas, mandiri, sehat, berbudi pekerti yang luhur dan berakhlak mulia. Pengasuhan yang positif perlu dilakukan oleh setiap orangtua dalam memberikan dukungan kesuksesan anak di masa depan.

Pada kenyataannya pola asuh positif yang diterapkan pada anak tidak selalu berhasil jika juga diterapkan pada anak yang lain karena pada prinsipnya, semua anak adalah unik, berbeda satu sama lain. Perbedaan dapat disebabkan karena usia, jenis kelamin, pola pengasuhan, latar belakang keluarga, kondisi lingkungan termasuk sosial budaya yang ada di masyarakat, temperamen, atau gaya belajar, ataupun berbagai perbedaan lainnya, sejak anak berada dalam kandungan, proses persalinan, hingga pasca persalinan. Meski demikian, ada sejumlah prinsip yang dapat digunakan dalam pengasuhan untuk tiap anak pada setiap kesempatan. Prinsip pengasuhan ada yang ditujukan secara internal untuk diri orang tua, guru atau orang dewasa lainnya. Ada juga prinsip yang ditujukan bagi pengondisian lingkungan anak (eksternal).

Pengasuhan orangtua saat mendampingi anak belajar dirumah selama pandemi akan memiliki kualitas jika dimanfaatkan juga untuk membangun kebersamaan antar anggota keluarga, Gloria (2020) menyatakan bahwa orangtua harus saling membantu satu sama lain,Bersama dengan anak, kemudian mengajak anak untuk berpartisipasi dalam pekerjaan rumah seperti membereskan mainan, membereskan tempat tidur, menyiram tanaman, dan lain-lain. Dengan demikian pengasuhan orangtua menjadi pengasuhan yang positif dan produktif dalam belajar dari rumah ditengah pandemic Covid-19.

Adapun penelitian terdahulu yang berhubungan dengan topik peneliti untuk dijadikan sebagai bahan referensi dalam menentukan metode yang akan digunakan untuk melakukan penelitian. Dalam penelitian (Tanjung, $\mathrm{R}$ 2020) bahwa Berdasarkan hasil analisis dan pembahasan penelitian maka peran orang tua dalam pendidikan anak usia dini, orang tua mengkondisikan lingkungan keluarga dengan menjadikan rumah sebagai tempat yang nyaman untuk menunjang pendidikan anak. Orang tua selalu berusaha meluangkan waktu untuk anak, masing-masing anggota keluarga juga diajarkan untuk terbuka dan saling menghargai melalui cara berkomunikasi yang sopan. Dalam kegiatan pembelajaran dirumah ,orang tua memiliki peran dalam segala hal.

Dari hasil penelitian tersebut dapat disimpulkan bahwa kesuksesan pembelajaran anak dirumah dimasa pandemic Covid-19 sangat berhubungan dengan peran orangtua dalam membimbing, mendampingi dan memfasilitasi selama kegiatan pembelajaran. 


\section{Metode}

Metode penelitian yang digunakan adalah studi pustaka sebagai bahan untuk mengkaji tujuh sampai sepuluh penelitian relevan mengenai pola pengasuhan positif orangtua selama belajar dari rumah dimasa pandemi covid-19 dengan mengumpulkan data pustaka, mencatat, dan membaca untuk memperoleh dasar-dasar dan pendapat secara tertulis yang dilakukan dengan cara mempelajari berbagai literatur yang berhubungan dengan masalah yang diteliti pada bulan Mei 2021. Menurut Nazir (2013 : 93) teknik pengumpulan data dengan mengadakan studi penelaah terhadap buku-buku, literatur-literatur, catatan-catatan, dan laporan-laporan yang ada hubungannyadengan masalah yang dipecahkan. Maka dari itu penulis ingin lebih jauh tentang bagaimana pengasuhan positif yang diterapkan orang tua dalam mendampingi anak belajar dari rumah selama pandemi Covid19. Teknik pengumpulan data yang digunakan oleh penulis adalah menggunakan dokumentasi, yang diperoleh kajian teoritis yang didapatkan dari buku, sumber yang relevan, browsing di Internet dan jurnal ilmiah.

\section{Hasil dan Pembahasan}

Masa pandemi Covid-19 di Indonesia saat ini semakin meningkat, belajar dari rumah merupakan salah satu upaya dalam memutus rantai penyebaran Covid-19 dan usaha dalam pemenuhan hak siswa dalam kegiatan pembelajaran. Hal ini menimbulkan masalah baru yang dialami oleh orangtua, seperti orangtua yang tidak sabar, kurangnya pemahaman materi, kesulitan dalam memotivasi dan mendorong anak dalam belajar, kesulitan jangkauan internet, dan kesulitan orangtua dalam mengoprasikan sistem pembelajaran dari rumah. Menurut hasil dari penelitian ini bahwa pengasuhan positif pada anak usia dini sangatlah penting. Peran orangtua sangat berpengaruh dalam pendampingan anak belajar dari rumah, hal ini sangat berpengaruh pada pola pengasuhan positif orangtuanya. Dalam penelitian berikut dapat diperoleh bahwa pola pengasuhan positif orangtua pada anak dimasa pandemi covid-19 adalah sebagai berikut :

\section{Mendampingi anak dalam mengerjakan tugas sekolah}

Dalam upaya pencegahan penularan virus Covid-19 pelaksanaan kegiatan pembelajaran sesuai dengan surat edaran Mendikbud No. 4 tahun 2020 tentang Pelaksanaan Kebijakan Pendidikan Dalam Masa Darurat Penyebaran Coronavirus Disease (Covid-19). Adanya kebijakan pemerintah untuk belajar dari rumah, maka peran yang biasanya dilaksanakan oleh satuan pendidikan, sekarang telah berganti fungsi disatuan keluarga yang menuntut orangtua terlibat aktif dalam mendampingi anak dengan pola asuh yang sesuai dalam kegiatan belajar dari rumah. (Euis Kurniat, 2020) menyatakan bahwa dari hasil wawancara dengan salah satu orangtua siswa adalah bahwa belajar dari rumah memerlukan bimbingan dari orangtua.Menurut Mattewakkang, (2020) dalam proses belajar dari rumah diharapkan guru beserta orang tua dapat mewujudkan pendidikan tidak hanya berfokus pada pencapaian akademik atau kognitif nya saja, tetapi 
dapat mewujudkan pendidikan yang bermakna, dibutuhkan saling pengertian dari pemerintah, sekolah, serta masyarakat. Posisi orang tua menjadi sangat penting dalam keberhasilan pendidikan anakanaknya sehingga perlu dibekali dengan panduan-panduan yang sesuai dengan kebutuhan anak saat ini. Seperti misalnya, panduan mengajarkan perilaku hidup bersih dan sehat, keterampilan menyelesaikan masalah, berfikir kritis, kolaborasi dan komunikasi, literasi informasi media dan teknologi, kreativitas dan inovasi serta ICT yang merupakan keterampilan-keterampilan yang dibutuhkan di abad 21. (Yulianingsih, wiwin,2020) mengatakan bahwa Berdasarkan hasil penelitian pada sub variabel pendampingan belajar anak sangat baik dengan persentase sebesar 82,59\%. Hal tersebut didukung dengan adanya kesesuaian jawaban pada sub variabel pendampingan belajar anak. diketahui sebagian besar orangtua memilih "Selalu" dengan persentase $51,79 \%$. Dalam hal ini dapat disimpulkan bahwa pada sub variabel pendampingan belajar anak lebih banyak memilih selalu. Maka, dengan demikian dilihat dari banyaknya orangtua yang memilih selalu dapat dikatakan bahwa pendampingan belajar anak sangat penting dalam mendukung kegiatan belajar anak selama belajar dari rumah dimasa pandemic Covid-19. Kegiatan mendampingi anak belajar, akan dimaknai lebih bagi anak itu sendiri. Mereka akan merasa diperhatikan dan disayangi. Ini menjadi poin penting dalam pengasuhan positif dalam pendampingan belajar dimasa pandemi anak tidak merasakan tertekan tetapi anak merasakan kenyamanan dan merasa senang dalam melakukan kegiatan belajar dirumah Bersama orangtua. Sesuai dengan hasil penelitian diatas dapat disimpulkan bahwa pendampingan belajar anak dirumah sangat penting dimasa Pandemi Covid-19.

\section{Mendukung dan memfasilitasi anak dalam belajar}

Dalam usaha pencapaian kegiatan pemebelajaran dari rumah dimasa pandemic Covid-19 orangtua dan guru harus memberikan motivasi dan fasilitas yang sesuai pada anak, agar anak tetap semangat dalam melaksanakan kegiatan pembelajaran dari rumah yang tentunya terasa bosan. Namun Sejalan dengan Hasbi,M (2020) bahwa Orang tua dan guru harus terus memberikan dukungan pada anak. Dorong anak untuk melakukan kembali apabila anak mengalami kegagalan dalam suatu kegiatan. Yakinkan pada anak untuk terus mencoba dan tidak takut salah. Kesempatan kedua tidak pernah siasia, selalu ada hikmah atau pelajaran yang bisa dipetik, serta diadaptasi. Seperti halnya Ketika anak belajar berjalan, berapa kali dia terjatuh untuk akhirnya dia berhasil berjalan sendiri, tanpa bantuan orang tua. Dalam dukungan pada anak diasa belajar dari rumah adalah memfasilitasi anak dengan aplikasi-aplikasi belajar pada anak yang menyenangkan agar anak tidak bosan.

Menurut Cahyati, N \& Kusumah, R. (2020). Dalam hasil penelitiannya disebutkan bahwa belajar dari rumah dimasa pandemic covid-19, membuat tidak sedikit orang tua yang sengaja untuk meluangkan waktunya demi dapat membantu proses pembelajaran anaknya selama di rumah.hal ini menjadi pengasuhan yang positif 
ketika orangtua mendukung dan memberikan fasilitas pada anak ketika belajar dari rumah. Ketika belajar salah satunya menyediakan Handphone/Laptop yang dapat dilakukan untuk mengakses laman pembelajaran daring.

\section{Menjalin komunikasi yang baik antar keluarga}

Mendukung kegiatan belajar anak dengan Menjalin komunikasi yang baik antar keluarga. Ditengah pandemic covid-19 orangtua yang bekerja diluar rumah dapat meluangkan waktunya lebih lama dirumah bersama anak,Anak usia dini juga merupakan manusia yang senantiasa membutuhkan kehadiran orang lain dan berinteraksi dengan orang lain dalam hidupnya. Dalam memenuhi kebutuhan tersebut individu akan berhubungan dengan orang lain dan melakukan penyesuian dengan lingkungan sekitarnya. Dalam mempererat hubungan antara anak dengan orangtua dapat dilakukan dengan perhatian, kasihsayang, dan melalui komunikasi yang menjadi hal penting. Murtiningsih, (2013) mengatakan bahwa komunikasi, orang tua mampu memahami keinginan dan kebutuhan anak serta orang tua dapat menyampaikan harapannya kepada anak tanpa memaksa. Untuk mewujudkan lingkungan rumah nyaman, aman dan menyenangkan, maka perlu adanya kehangatan dalam komunikasi antar anggota keluarga.

Komunikasi positif dapat diterima dengan mudah pada anak usia dini jika pesan yang disampaikan jelas, pesan yang di sampaikan bertahap dan penuh kesopanan.biasakan mengajak anak untuk berkomunikasi positif agar kegiatan pembelajaran berjalan dengan baik.kegiatan komunikasi yang intens dilingkungan keluarga dapat menjadikan suasana keluarga yang hangat dan nyaman. Anak juga akan semangat dalam kegiatan belajar. Prianto (2020) Mengatakan bahwa dalam pendampingan belajar dari rumah selain membantu anak dalam proses belajar juga akan membangun komunikasi yang intens dengan anak. Komunikasi yang intens ini akan membangun kreativitas anak lewat berbagai aktivitas bersama yang bermanfaat .

\section{Memilih pola asuh yang tepat}

Dengan mendukung dan memfasilitasi anak dalam belajar dengan memilih pola asuh yang tepat. Dalam pendampingan belajar, pola asuh sangat penting bagi anak agar anak mampu beradaptasi dalam lingkungan keluarganya. Pola asuh orangtua dalam mengasuh anak ada tiga macam menurut Hurlock (1999) yang pertama yaitu Pola Asuh Permissif yang dapat diartikan sebagai pola yang membebaskan anak untuk melakukan apa yang ingin dilakukan tanpa mempertanyakan. Pola asuh ini tidak menggunakan aturan-aturan yang ketat bahkan bimbingan pun kurang diberikan, sehingga tidak ada pengendalian atau pengontrolan serta tuntutan kepada anak. Kebebasan diberikan penuh dan anak diijinkan untuk member keputusan untuk dirinya sendiri, tanpa pertimbangan orang tua. Anak berperilaku sesuai dengan keinginannya tanpa adanya kontrol dari orang tua yang kedua adalah Pola Asuh Otoriteryaitu suatu pola ketika orang tua menerapkan aturan dan batasan yang mutlak harus ditaati, 
tanpa memberi kesempatan pada anak untuk berpendapat, jika anak tidak mematuhi akan diancam dan dihukum. Pola asuh otoriter ini dapat menimbulkan hilangnya kebebasan pada anak, kurangnya inisiatif dan aktivitasnya, sehingga anak menjadi tidak percaya diri pada kemampuannya. Dan yang ketiga adalah Pola Asuh Demokratis, yaitu menanamkan disiplin kepada anak, dan menghargai kebebasan yang tidak mutlak, dengan bimbingan yang penuh pengertian antara anak dan orang tua, memberi penjelasan secara rasional dan obyektif jika keinginan dan pendapat anak tidak sesuai. Dalam pola asuh ini, tumbuh rasa tanggung jawab pada anak, dan pada akhirnya, mampu bertindak sesuai dengan norma yang ada.Pembentukan anak bermula atau berawal dari pengasuhan orang tua terhadap anak-anaknya sangat menentukan dan memengaruhi kepribadian (sifat) serta perilaku anak. (Muslimah, 2020)

Memilih pola asuh yang dapat digunakan dalam pendampingan kegiatan pembelajaran anak dirumah dengan memilih pola asuh yang tepat, Pola asuh Demokratis dapat digunakan oleh orangtua karena selama pengasuhan orang tua cenderung bersikap responsif, bersahabat dengan anak dan mampu mengontrol dirinya dalam memberikanp pengasuhan. Dalam pola asuh demokratis orang tua juga dapat memberikan hak anak yang dapat memberikan dampak positif bagi anak, Dalam hal ini orangtua dapat memberikan pembelajaran pada anak dalam bertanggung jawab terhadap tindakan yang mereka lakukan pada orang lain.

\section{Menghargai pendapat anak}

Pendampingan belajar dirumah pada anak usia dini dirumah dapat membentuk keharmonisan keluarga salah satunya dengan menghargai pendapat anak ketika anak mengutarakan sesuatu sebagai orangtua bisa mendengarkan dengan penuh perhatian dan menghargai tidak menyibukan diri seperti bermain telepon genggam anak akan merasa tidak dihargai oleh orangtuanya yang dapat muncul sifat ketidak keterbukaannya, dalam mendidik anak hindari kesalahan kesalahan kecil yang dapat mengubah karakteristik anak melalui komunikasi,kesalahan yang terjadi adalah gaya komunikasi memerintah, mengancam, menceramahi, menginterogasi, memberi label, membandingkan, menghakimi, menyalahkan, mendiagnosis, menyindir, memberi solusi, menyuap, dan membohongi (Risman, 2016). Sikap keluargaanya dalam menghargai anak sangat berpengaruh dalam kegiatan belajarnya, misalnya anak lebih semangat dan lebih percaya diri dalam mengungkapkan pendapatnya.

\section{Membuat Peraturan Dirumah}

Hal ini sangat penting dilakukan oleh orangtua dalam pengasuhan positif saat belajar dirumah, karena emosi anak masih cenderung berubah-ubah hal ini sesuai dengan Santrock (2007) yang mengatakan bahwa perkembangan emosi pada masa kanak-kanak awal ditandai dengan munculnya emosi evaluatif yang disadari rasa bangga, malu, dan rasa bersalah, dimana kemunculan emosi ini 
menunjukkan bahwa anak sudah mulai memahami dan menggunakan peraturan dan norma sosial untuk menilai perilaku mereka.

Memberikan peraturan seperti mandi sebelum kegiatan belajar di rumah, bermain gadget 2 jam dalam sehari yang mencangkup kegiatan pembelajaran daring. Pada pemberian aturan dirumah juga anak menyetujui dan bisa memberikan atau menambahkan sebuah peraturan dan untuk disepakati Bersama antara orangtua dan anak. Yang pada akhirnya kegiatan belajar dari rumah dapat efektif dan dapat berjalan dengan baik.

\section{Memberikan sebuah hadiah penghargaan (Reward)}

Saat anak mampu menggapai keberhasilan pada kegiatan pembelajaran dirumah, sebagai orang tua dapat memberikan sebuah penghargaan dengan mmberikan apresiasi positif pada anak, dapat berupa materi dan memberikan fasilitas blajar yang lebih baik. Jika reward itu adalah alat untuk mendidik, reward tidak boleh bersifat seperti upah karena upah ialah sesuatu yang mempunyai nilai sebagai ganti rugi dari suatu pekerjaan (Rosyid, Abdullah, 2018:39).

Dalam memberikan reward, orangtua dan anak dapat menyesuaikan dengan membuat keputusan bersama untuk mendapatkan sebuah rewardseperti membuat persyaratan, anak akan lebih disiplin lagi dan lebih bersemangat melakukan hal-hal yang dapat membuatnya ia mendapatkan pujian orangtuanya. Memberikan sebuah reward pada anak juga memberikan dampak positif seperti anak lebih disiplin mengerjakan tugas, siswa lebih aktif, pembelajaran menjadi menyenangkan, Penerapan reward yang tidak menyesuaikan dengan situasi dan kondisi serta pencapaian yang telah dilakukan siswa akan menimbulkan dampak negatif misalnya terjadi kecemburuan antara kakak adik dan reward menjadi sebab disiplinnya siswa dalam belajar.

\section{Kesimpulan}

Pengasuhan positif dalam pendampingan anak belajar dari rumah ditengah pandemic Covid-19 sangat penting dilakukan dapat dilihat dari hasil kajian pustaka, Adapun hasilnya adalah orangtua mendampingi anak dalam mengerjakan tugas sekolah, mendukung dan memfasilitasi anak dalam belajar, menjalin komunikasi yang baik antar keluarga, memilih pola asuh yang tepat ,menghargai pendapat anak, membuat peraturan dirumah dan memberikan sebuah hadiah penghargaan (Reward). Peran orangtua sangat berpengaruh dalam pendampingan anak belajar dari rumah. Dengan demikian anak tidak akan merasa sendiri dan lebih semangat dalam mengikuti pembelajaran dari rumah.

\section{Daftar Pustaka}

NN. 2021.https://covid19.go.id/ .Diakses (27 Januari 2021)

Adit,Albertus.(2020). Ini Kendala Orangtua dampingi anak PAUD belajar dirumah. Diakses pada 27 Februari 2021, dari 
https://edukasi.kompas.com/read/2020/07/22/090351771/inikendala-orangtua-dampingi-anak-paud-belajar-di-rumah?page=all.

NN.(2015). Pola Asuh Positif untuk anak. Diakses pada 3 Maret 2021. Darihttps://www.parenting.co.id/usia-sekolah/pola-asuh-positifuntuk-anak

Nafisah, U. L., \& Kirana, D. P. (2021). Penerapan Reward untuk Meningkatkan Disiplin Anak dalam Belajar. Kiddo: Jurnal Pendidikan Islam Anak Usia Dini, 2(1), 14-26.

Jamiatul, J., Maghfiroh, M., \& Astuti, R. (2020). Pola Asuh Orang Tua danPerkembangan Moral Anak Usia Dini (Studi Kasus di TK AlGhazali Jl. Raya Nyalaran Kelurahan Kolpajung Kecamatan Pamekasan Kabupaten Pamekasan). Kiddo: Jurnal Pendidikan Islam Anak Usia Dini, 1(1), 1-9.

Windhiyana, E. (2020). Dampak Covid-19 terhadap kegiatan pembelajaran online di sebuah perguruan tinggi kristen di Indonesia. Perspektif Ilmu Pendidikan, 34(1), 1-8.

Hasbi,M, dkk. (2020). Pengasuhan Positif. Jakarta. Kemdikbud.

Hasbi,M, dkk. (2020). Membangun Komunikasi Positif Antara Guru PAUD dengan OrangTua Murid Pada Saat Penerapan Kebijakan Belajar dari Rumah. Jakarta. Kemdikbud.

Iftitah, S. L., \& Anawaty, M. F. (2020). Peran Orang Tua Dalam Mendampingi Anak Di Rumah Selama Pandemi Covid-19. JCE (Journal of Childhood Education), 4(2), 71-81.

Kurniati, E., Alfaeni, D. K. N., \& Andriani, F. (2020). Analisis Peran Orang Tua dalam Mendampingi Anak di Masa Pandemi Covid-19. Jurnal Obsesi: Jurnal Pendidikan Anak Usia Dini, 5(1), 241-256.

Sofyan, I. (2019). Mindful Parenting: Strategi Membangun Pengasuhan Positif dalam Keluarga. Journal of Early Childhood Care and Education, 1(2), 41-47.

Wardani, A., \& Ayriza, Y.(2020). Analisis kendala orang tua dalam mendampingi anak belajar di rumah pada masa pandemi Covid-19. Jurnal Obsesi: jurnal Pendidikan anak usia dini, 5(1), 772-782.

Nurmalitasari, F. (2015). Perkembangan sosial emosi pada anak usia prasekolah. Buletin Psikologi, 23(2), 103-111.

Cahyati, N., \& Kusumah, R. (2020) Peran Orang Tua Dalam Menerapkan Pembelajaran Di Rumah Saat Pandemi Covid 19. Jurnal Golden Age, 4(01), 152-159. 
Wardani, A., \& Ayriza, Y. (2020). Analisis kendala orang tua dalam mendampingi anak belajar di rumah pada masa pandemi Covid-19. Jurnal Obsesi: jurnal Pendidikan anak usia dini, 5(1), 772-782.

Yulianingsih, W., Suhanadji, S., Nugroho, R., \& Mustakim, M. (2020). Keterlibatan Orangtua dalam Pendampingan Belajar Anak selama Masa Pandemi Covid-19. Jurnal Obsesi: Jurnal Pendidikan Anak Usia Dini, 5(2), 1138-1150.

Nooraeni, R. 2017. Implementasi Program Parenting Dalam Menumbuhkan Perilaku Pengasuhan Positif Orang Tua Di PAUD Tulip Tarogong Kaler Garut. Jurnal Pendidikan Luar Sekolah, 13(2).

Dewi, P. A. S. C., \& Khotimah, H. (2020). Pola Asuh Orang Tua Pada Anak Di Masa Pandemi Covid-19. In Seminar Nasional Sistem Informasi (SENASIF) (Vol. 4, No. 1, pp. 2433-2441).

Wahyuseptiana, Y. I. (2020). Pembentukan Konsep Penerimaan Diri pada Anak Usia Dini di Masa Pandemi Covid-19. BUANA GENDER: Jurnal Studi Gender dan Anak, 5(2), 126-136.

Rachman, S. A. (2020). Penguatan Peran Orang Tua Dalam Mendapingi Pendidikan Anak Usia Dini Di Masa Pandemi Covid-19. Jurnal Golden Age, 4(02), 322-331.

Tanjung, R. (2020). Peran Orangtua dalam Pendidikan Anak Usia Dini di Masa Pandemi Covid-19. Murhum: Jurnal Pendidikan Anak Usia Dini, 64-73. 